\title{
Officers' Placement Model Based on Job Analysis in North Aceh Government
}

\author{
Muryali1 $^{1,}$, Endang Larasati ${ }^{2}$, Hardi Warsono ${ }^{3}$, Tri Yuniningsih ${ }^{4}$ \\ ${ }^{1}$ Public Administration Departement, Faculty of Social and Political Sciences, \\ Faculty of Social and Political Sciences, Malikussaleh University, Lhokseumawe, Indonesia \\ 2,3,4 Public Administration Departement, Faculty of Social and Political Sciences, \\ Faculty of Social and Political Sciences Diponegoro University,Semarang, Indonesia \\ *Email : muryali.adp@unimal.ac.id
}

\begin{abstract}
The use of job analysis is to improve organizational and individual performance in organizations. The implementation of job analysis can ease employees to understand the positions that are being occupied. The organization will have the convenience of placing employees based on their abilities and capacities. Qualitative methods using descriptive approach was used in this study. The results showed that the implementation of job analysis in the placement of officials in North Aceh still varied. In addition, it still prioritized administrative requirements and ignored employee's work experience. In general, employees who have the ability and capacity do not have the opportunity and information about the placement of officials.
\end{abstract}

Keywords: Job Analysis, Placement of Officials, Employees' capacity

\section{INTRODUCTION}

One's position in an organization greatly influences the progress of the organization. Each level of structural position has different responsibilities. To carry out the responsibilities, employees are required to possess sufficient ability and expertise in that position because they play an important role in the organization, including public organizations such as government bureaucracy. Widhyarto (2004) states that human resources are not only seen as a tool of management, but it must be viewed as a valuable organizational asset, especially those with reliable abilities and good knowledge.

A skilled and reliable employee will perform well which can assist the organization to achieve the desired goals. In the case of government organization, the main objective is to provide good public services and carry out good governance. Therefore, local government leaders must maintain and reward employees who have good ability and work performance. 
An official's position placement based on their abilities is one of the rewards received by every employee, meaning placing people in the right position. Such placement is similar to boosting employees confidence as they are capable on the position assigned. In other words, appropriate recruitment methods to develop employees' capability are desirable so that they will improve their capability more.

Regional government bureaucracies have generally recruited officials, namely employees who will be placed in certain positions by looking at career and administrative levels. If this method is used in assigning employees to certain positions, it will not work because they do not carry out an objective assessment.

To conduct an objective assessment, it is necessary to carry out job analysis as suggested in government regulation number 11 of 2007 concerning personnel management that every agency needs to carry out a job analysis. The use of it in the bureaucracy is to find out the compatibility between the ability of the employee and a certain position. This means that each position has different duties, functions and workloads. Thus, it is necessary to assign the right people as Sowarno (1992) argues that the basis for a wellconsidered placement is the ability of an employee.

However, in reality in North Aceh, the implementation of job analysis has not been optimally carried out. There are several obstacles in the process of assigning employees to certain positions. At present, North Aceh Government is conducting a position analysis through a position auction or by means of a merrit system. Yet, this process has not been fully able to find officials who match the capabilities of the positions.

The auction process for positions, transfers, and promotions in North Aceh from 2019 to 2020 has been carried out several times. There were 4 stages of inaugurating echelon II and III officials in 2019 while there were 3 stages of inaugurating echelon II and III officials in 2020. Based on these data, North Aceh government has carried out an official overhaul with the aim of placing employees who are suitable for their abilities in certain positions with the expectation of being able to improve performance and to contribute well towards the implementation of North Aceh government.

Nevertheless, in practice, there are still many shortages of public services and many officials' performance have not achieved satisfactory results yet. Moreover, the number of North Aceh employees who fulfill the administrative requirements has exceeded the available positions. Therefore, North Aceh government, through authorized officials, can recruit officials with precise and correct job analysis. This means that the objective placement of officials is the conformity between the knowledge and skills possessed by the employee with the conditions required.

Currently, there are 35 echelon II and 351 echelon III in North Aceh. 
Meanwhile, the total number of civil servants in North Aceh government is 12,600 people. In relation to this, an authorized official can select the right official who have the ability to be placed in a position according to their abilities and skills. This means that analyzing a position should not only be seen from administrative point of view and previous levels of position.

With improper placement of officials and the mismatch between position and skills, it will be difficult to improve performance and provide good public services. Likewise, regional development will lag behind from other regions. Therefore, this study attempted to investigate problems in job analysis process and find the right model for officials placement which suit employees' abilities.

\section{LITERATURE REVIEW}

In job analysis, there are two main points that need to be considered; job descriptions and job requirements. Job description seeks the responsibilities, obligations, working conditions, performance, and activities of the position. Menawhile, job requirements are education level, experience related to the position, and the ability required by the position (Moekijat, 1998: 35). Based on this opinion, it is clear that in order to analyze the position, it is necessary to have employees who have the ability needed for the position. In addition, training and education are also the focus of job analysis.
Mathis and Jackson (2000) develop five stages in job analysis process that should be conducted in an effective manner:

a. Planning the job analysis

b. Preparing and communicating the job analysis

c. Conducting the job analysis

d. Developing job descriptions and job specifications

e. Maintaining and updating job description and job specification According to Desler (2013), there are several information as the basis for job analysis:

a. Work activity

b. Human behavior

c. Work equipment used

d. Performance standards

e. Work context

f. Personnel requirements

Furthermore, Ivancevich (1992) describes the steps of job analysis. The knowledge and data collected from step 1 to step 6 are used as the basis for any other human resource management activities such as recruitment, selection, training, performance evaluation, and compensation. Besides, it is also used as input for the design and redesign of positions.

Some of the experts' opinion above are important subject because it will benefit both individuals and organization as stated by Samsudin (2006):

Benefits for Individuals: 1) Influencing and determining the standard of living as well as describing the socioeconomic status; and 2) The greater a person's income, the more opportunities to meet their needs in a 
quality and satisfying manner. Benefits for the organization: 1) A vehicle for manifesting existence and achieving its goals, and; 2) Productive and quality job producing quality products and services.

\section{RESEARCH METHODS}

This research is a qualitative study examining the placement model of officials based on an analysis of positions in North Aceh. The selection of research informants was determined purposively with certain considerations (Sugiyono, 2015). Informants were those who know indepth about the problems under study so that accurate data and information were obtained in accordance with the facts of the various parties involved. The informants were the Regent of North Aceh, the Regional Secretary, the Head of the Civil Service Agency, several Eschelon Officials and several civil servants. The data collection technique was carried out through indepth interviews, observation, FGD, and documentation. Furthermore, data was analyzed using interactive qualitative analysis through three steps: data condensation, presentation, and drawing conclusions or verification (Miles, Huberman (2014). Then, data was validated through source triangulation techniques, technical triangulation techniques, and time triangulation.

\section{RESULT AND DISCUSSION 4.1. Job Analysis}

The division of tasks needs to maintain a balance between abilities and responsibilities. It is expected that job analysis can prevent gaps between the capabilities and workload of each official who will be placed in a particular position. For the time being, North Aceh government assign employees by selecting through interviews. As a result, there are some positions that do not match the skills and workloads meaning that the process of job analysis carried out in North Aceh is not in line with expectations in good governance.

\subsection{Employee Skills and Workload}

Every employee is required to have skills and abilities because this is the main asset for each employee to work. The skills possessed will receive an appropriate workload, especially those who will occupy the position. In general, employees in the North Aceh government have attended various types of training, meaning that many North Aceh employees have the skills required in the available positions. However, what becomes an obstacle is that not all employees, especially those who have good skills, have the opportunity to contribute to government administration. This becomes obstacle experienced by employees due to the lack of information received from the staffing manager.

\subsection{Employee Capacity}

The main asset for employees is skills because without skills it is impossible to carry out the tasks assigned to them. This means that to achieve employee work performance requires a somewhat high standard of 
ability. Thus, the capacity of employees can help to achieve job targets in working positions. From the results of the research, the capacity of staff in North Aceh District has met the standards. However, a matter causing employees to not increase in performance is due to the nonobjective division of tasks because in job analysis carried out did not analyze job descriptions. This means that each position has a different task and a different workload. So, the division of tasks should be seen from the capacity of the employees.

\subsection{Job Description}

Based on job description in the provious organization, the employee's capability can be identified because the it is a tool to divide tasks among employees in the organization implying that type of position, the space for the duties to be carried out, the requirements for officials, and the capacity of the officials within a certain time is revealed. Before starting to work, employees need to describe the workload that will be carried out within a certain time. From the results of research, in North Aceh, there is still frequent overlapping work, so it is very difficult for employees to complete their duties according to the predetermined time. This becomes an obstacle for employees in increasing performance as it is difficult to achieve. Consequently, many employees are not motivated to contribute to the organization.

\subsection{Job requirements}

It is required for employees to have certain capability in performing their jobs. Generally, to identify whether employees are capable or not, employers look at the level of education, training, work experience, and psychological and physical abilities. However, all these are not sufficient to place an employee in a certain position. These requirements are the first step to know that an employee has the qualifications to be placed in a certain position. The research finds that every North Aceh government agency, job requirements are only administrative. Meanwhile, experience and skills are often neglected in selecting employees so that there are employees who are not able to carry out their duties as expected by the organization.

\section{CONCLUSION}

Basically, job analysis for the placement of employees in North Aceh has been carried out as ordered by the Law Number 5 of 2014 concerning ASN and PP. Number 7 of 2017 concerning personnel management. It can be seen that every official who is placed in a certain position is not legally defective. Besides, echelon II officials in Aceh generally hold a master's degree showing that the level of education has become a concern in placing employees in strategic positions. Meanwhile, the aspect of experience is often neglected in the placement of positions in North Aceh because it is often trapped by administrative requirements. Instead, experinece should be the second 
consideration after administrative requirements. The implementation of job analysis in North Aceh still varies, especially the standardization of job requirements. As a consequence, this becomes a weakness in implementing job analysis as decisions made in assigning officials do not match the results of job analysis.

Job analysis application should be implemented with a concept that is in accordance with the conditions of the organization the available human resources. In addition, the placement of officials must be suitable with the results of the job analysis. Thus, the professionalism of the placement of officials and the trust of employees of officials will be guaranteed. Also, it is expected that the public will increase in the government bureaucracy in order to create a more conducive, cooperative, and harmonious working atmosphere among employees, employers, officials, leaders, and subordinates.

\section{REFERENCES}

Dessler, G. (2013) Manajemen Sumber Daya Manusia Jilid 1. Edisi 10, Jakarta: Indeks

Mathis, R. L, and Jackson, J.H. (2000), Human Resource Management 10th Edition, Thomson South -Western, United States

Miles, Huberman.2014. Qualitatif Data Analysis, Third edition, SAGE Publication.Inc, ISBN 978-1-4522-5787-7

Moekijat (1999), Manajemen Sumberdaya Manusia (Manajemen Kepegawaian), Bandung: Mandar Maju

Samsudin, S. (2006). Manajemen Sumber Daya Manusia. Bandung: Pustaka Setia.

Sugiyono.2015. Metode Penelitian Kombinasi (Mix Methods), Cetakan ke 7, Alfabeta,CV,Bandung 